\title{
A Cautionary Note on the Use of Monin-Obukhov Similarity Theory in Very High-Resolution Large-Eddy Simulations
}

\author{
Sukanta Basu ${ }^{1}$ (D) Avraham Lacser ${ }^{2,3}$
}

Received: 26 July 2016 / Accepted: 8 December 2016 / Published online: 9 January 2017

(C) The Author(s) 2017. This article is published with open access at Springerlink.com

\begin{abstract}
In several recent large-eddy simulation studies, the lowest grid level was located well within the roughness sublayer. Monin-Obukhov similarity-based boundary conditions cannot be used under this scenario, and in this note we elaborate on this fundamental problem and suggest potential solutions.
\end{abstract}

Keywords Inertial sublayer - Large-eddy simulation · Monin-Obukhov similarity theory · Roughness sublayer · Surface layer

In the era of petascale computing, very high-resolution (the grid size, $\Delta=O(1) \mathrm{m}$ or finer) large-eddy simulation (LES) of atmospheric boundary-layer (ABL) flows is gradually becoming a norm. For example, in a recent study (Sullivan et al. 2016), $\Delta=0.39 \mathrm{~m}$ was utilized in the idealized simulation of the stable boundary layer. It is a well-known fact that all the contemporary LES codes utilize the conventional Monin-Obukhov similarity theory (MOST) as lower boundary conditions (e.g., Heus et al. 2010; Maronga et al. 2015). It is also common knowledge (e.g., Lumley and Panofsky 1964; Monin and Yaglom 1971; Wyngaard 2010) that MOST is only valid for heights $z \gg z_{\circ}$, where $z_{\circ}$ is the aerodynamic roughness length. MOST is not applicable for $z<\alpha h$, where $h$ denotes the height of the roughness elements. Typically, $\alpha$ is assumed to be between 2 and 5 based on laboratory studies (see Raupach et al. 1991, and references therein). Unfortunately, a number of recent LES studies (e.g., Beare et al. 2006; Basu et al. 2011; Maronga 2014; Sullivan et al. 2016; Udina et al.

Sukanta Basu

s.basu@tudelft.nl

Avraham Lacser

avil@iibr.gov.il

1 Faculty of Civil Engineering and Geosciences, Delft University of Technology, Delft, The Netherlands

2 Department of Marine, Earth, and Atmospheric Sciences, North Carolina State University, Raleigh, NC 27695, USA

3 Present Address: Environmental Sciences Division, IIBR, POB 19, 74100 Ness Ziona, Israel 


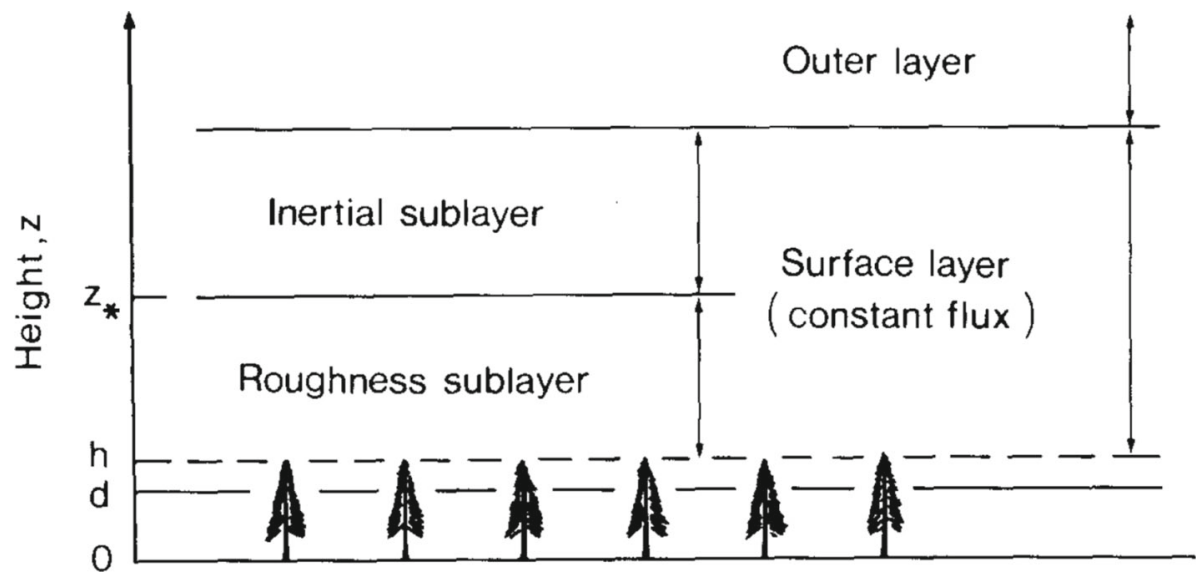

Fig. 1 The surface layer and its sublayers (taken from Raupach and Legg 1984)

2016) prescribed the lowest grid levels $\left(z_{1}\right)$ within the range $0<z_{1}<\alpha h$ and inappropriately invoked MOST-based boundary conditions. The purpose here is to highlight this undesirable oversight.

The schematic in Fig. 1 depicts the canonical structure of the atmospheric surface layer, with the roughness elements located on the substrate surface $z=0 .{ }^{1}$ The so-called displacement height is denoted by $d$ (Jackson 1981; Raupach and Legg 1984). MOST (including the logarithmic law of the wall) is valid within the inertial sublayer (ISL), where the lower limit of the ISL is $z_{*}(=\alpha h)$ and the upper limit is usually taken as the $10 \%$ of the boundary-layer height. In the roughness sublayer (RSL; also known as the transition layer), surface-wake generation and interactions dominate and the flow is quite heterogeneous in comparison with that in the ISL. Furthermore, due to enhanced mixing, wind shear in the RSL is significantly less than that in the ISL. In his classic book (pp. 142-143), Townsend (1976) wrote:

For fully rough flow at large values of Reynolds number, $z_{\circ}$ is commonly about onetenth of the average height of the roughness elements and the logarithmic distribution can be valid only at heights considerably larger than that, say for $z / z_{\circ}$ greater than fifty.

In other words, according to Townsend (1976): $h / z_{\circ} \approx 10$ and $z_{*} / z_{\circ} \approx 50$. Other estimates and formulations of $h / z_{\circ}$ from experimental studies have been summarized in, e.g., Raupach et al. (1991) and Jiménez (2004). One of the first studies documenting values of $z_{*} / z_{\circ}$ in the ABL was due to Tennekes (1973), who put an estimate of 100 along with a candid note "of course, that is relatively arbitrary, because firm estimates of the accuracy cannot yet be made." In the following years, significant contributions were made by Garratt (1978, 1980, 1983 , 1992) who, based on observations from the Koorin experiment, reported $z_{*} / z_{\circ}$ to vary from 35 to 150 for the wind profile under unstable conditions. For temperature, he found $z_{*} / z_{\circ} \approx 100$ (Garratt 1980). For stably stratified conditions, $z_{*} / z_{\circ}$ for the wind profile was found to be significantly lower, approximately in the range of 11-55 (Garratt 1983). Based on past field and laboratory studies (e.g., Garratt 1980, 1983; Raupach et al. 1991), it is quite evident that, in addition to atmospheric stability, the geometric nature of roughness elements also contributes significantly to the variability in this ratio. Recently, Huang et al.

1 Some studies (e.g., Garratt 1980, 1983) use a different convention and assume the origin of $z$ at the zero-plane displacement. 
(2016) analyzed an extensive database comprising several direct numerical simulations and wind-tunnel experiments. They reported the parameter $\alpha\left(=z_{*} / h\right)$ to be within the range of 1.2-2.2 for neutrally stratified flows and, in agreement with earlier studies, also found $\alpha$ to be strongly dependent on the geometric details (e.g., roughness element shape and interelement spacing).

Based on the above discussion, we strongly advocate that for future LES studies, the lowest grid level $\left(z_{1}\right)$ should not be prescribed at heights $z<z_{*}$. In lieu of any universal criterion, we recommend that the modelling community follows a tentative guideline of $z_{1}>50 z_{0}$. Thus, for a value of $z_{\circ}=0.1 \mathrm{~m}$ (e.g., in the GABLS-1 LES intercomparison study ${ }^{2}$ ), one should use $z_{1}>5 \mathrm{~m}$.

Please note that similar guidelines are already followed in the dispersion modelling and wind engineering communities. In the context of regulatory modelling applications, the US Environmental Protection Agency (Bailey 2000) recommended that wind speed and direction data should always be collected from $z \geq \max \left(20 z_{\circ}, 1 \mathrm{~m}\right)$. Blocken et al. (2007) noted the following condition as one of the four criteria for computational fluid dynamics simulations:

A distance $y_{P}$ from the centre point $P$ of the wall-adjacent cell to the wall (ground surface) that is larger than the physical (or geometrical) roughness height $K_{S}\left(y_{P}>K_{S}\right)$.

For fully rough flows, the sand-grain roughness $\left(K_{S}\right)$ is related to the aerodynamic roughness length (Blocken et al. 2007): $z_{\circ} \approx K_{S} / 30$. In other words, $y_{P}$ (i.e., $z_{1}$ in our notation) should be $>30 z_{0}$.

We point out that our proposed guideline may be insufficient for transitional rough surfaces. Recently, Marusic et al. (2013) analyzed surface-layer data from both laboratory experiments and field measurements from the SLTEST site over Utah's western desert. They proposed a conservative limit of $z_{*}$ as a function of the friction Reynolds number $\left(R e_{\tau}\right)$,

$$
\frac{z_{*} u_{*}}{v}=3 \sqrt{R e_{\tau}}
$$

For the SLTEST data, Marusic et al. (2013) reported: $u_{*}=0.188 \mathrm{~m} \mathrm{~s}^{-1}, v=1.8 \times 10^{-5} \mathrm{~m}^{2}$ $\mathrm{s}^{-1}$, and $R e_{\tau}=6.3 \times 10^{5}$. Using Eq. 1, we obtain $z_{*}=0.23 \mathrm{~m}$, while the sand-grain roughness $\left(K_{S}\right)$ for this case is $2 \mathrm{~mm}$. Since this dataset represents a mildly transitional rough surface (Marusic et al. 2013), we utilize Eqs. 4.4 and 4.5 of Kunkel and Marusic (2006) to estimate $z_{\circ}=3.5 \times 10^{-5} \mathrm{~m}$. Clearly, the ratio $z_{*} / z_{\circ}$ is several order larger than the corresponding fully rough values. If one were to perform a large-eddy simulation for this specific SLTEST case, the lowest grid point would need to be $>0.23 \mathrm{~m}$.

We speculate that for most idealized LES problems the guideline of $z_{1}>50 z_{\circ}$ suffices. As a viable alternative, one could also use modified MOST relationships (with an RSL correction) as boundary conditions in conjunction with $z_{1}<z_{*}$. For example, Physick and Garratt (1995) proposed such a formulation for mesoscale models that could be utilized in LES codes (with minor modifications). Other empirical formulations also exist in the forest and urban canopy turbulence literature (e.g., de Ridder 2010; Arnqvist and Bergström 2015). For neutrally stratified flows, the generalized law-of-the-wall proposed by Huang et al. (2016) is another potential candidate. Incorporation of such a formulation in contemporary LES codes should not be a challenging task.

For idealized simulations over homogeneous surfaces, several LES codes utilize the MOST-based boundary conditions locally (e.g., Stoll and Porté-Agel 2008) and others use a

2 The acronym GABLS stands for GEWEX (The Global Energy and Water Cycle Exchanges Project) Atmospheric Boundary Layer Study. 
planar-averaged option (e.g., Basu and Porté-Agel 2006). Even though the concept of the RSL is formally applicable for ensemble averages, we recommend employing the RSL corrections for both types of boundary conditions.

For LES of the stable boundary layer, several studies have shown that with increasing resolution the surface fluxes decrease monotonically, and in turn, the boundary-layer height decreases. As an illustrative example, refer to Fig. 1 and Table 1 in Sullivan et al. (2016). We hypothesize that, due to the lack of RSL corrections in the very high-resolution simulations of Sullivan et al. (2016), mixing near the surface has been reduced spuriously, and (partially) contributed to an artificial resolution sensitivity.

Acknowledgements The first author is grateful to Peter Sullivan for providing insights into the roughness problem.

Open Access This article is distributed under the terms of the Creative Commons Attribution 4.0 International License (http://creativecommons.org/licenses/by/4.0/), which permits unrestricted use, distribution, and reproduction in any medium, provided you give appropriate credit to the original author(s) and the source, provide a link to the Creative Commons license, and indicate if changes were made.

\section{References}

Arnqvist J, Bergström H (2015) Flux-profile relation with roughness sublayer correction. Q J R Meteorol Soc 141:1191-1197

Bailey DT (2000) Meteorological monitoring guidance for regulatory modeling applications. Tech. Rep. EPA454/R-99-005, United States Environmental Protection Agency

Basu S, Porté-Agel F (2006) Large-eddy simulation of stably stratified atmospheric boundary layer turbulence: a scale-dependent dynamic modeling approach. J Atmos Sci 63:2074-2091

Basu S, Holtslag AAM, Bosveld FC (2011) GABLS3 LES intercomparison study. In: ECMWF/GABLS Workshop on "Diurnal cycles and the stable atmospheric boundary layer", ECMWF, pp 75-82

Beare RJ, Macvean MK, Holtslag AAM, Cuxart J, Essau I, Golaz JC, Jimenez MA, Khairoutdinov M, Kosovic B, Lewellen D, Lund TS, Lundquist JK, Mccabe A, Moene AF, Noh Y, Raasch S, Sullivan P (2006) An intercomparison of large-eddy simulations of the stable boundary layer. Boundary-Layer Meteorol 118:247-272

Blocken B, Carmeliet J, Stathopoulos T (2007) CFD evaluation of wind speed conditions in passages between parallel buildings-effect of wall-function roughness modifications for the atmospheric boundary layer flow. J Wind Eng Ind Aerodyn 95:941-962

de Ridder K (2010) Bulk transfer relations for the roughness sublayer. Boundary-Layer Meteorol 134:257-267

Garratt JR (1978) Flux profile relations above tall vegetation. Q J R Meteorol Soc 104:199-211

Garratt JR (1980) Surface influence upon vertical profiles in the atmospheric near-surface layer. Q J R Meteorol Soc 106:803-819

Garratt JR (1983) Surface influence upon vertical profiles in the nocturnal boundary layer. Boundary-Layer Meteorol 26:69-80

Garratt JR (1992) The atmospheric boundary layer. Cambridge University Press, Cambridge, 316 pp

Heus T, van Heerwaarden CC, Jonker HJJ, Siebesma AP, Axelsen S, van den Dries K, Geoffroy O, Moene AF, Pino D, de Roode SR, Vilà-Guerau de Arellano J (2010) Formulation of the Dutch atmospheric large-eddy simulation (DALES) and overview of its applications. Geosci Model Dev 3:415-444

Huang G, Simoëns S, Vinkovic I, Le Ribault C, Dupont S, Bergametti G (2016) Law-of-the-wall in a boundarylayer over regularly distributed roughness elements. J Turbul 17:518-541

Jackson PS (1981) On the displacement height in the logarithmic velocity profile. J Fluid Mech 111:15-25

Jiménez J (2004) Turbulent flows over rough walls. Annu Rev Fluid Mech 36:173-196

Kunkel GJ, Marusic I (2006) Study of the near-wall-turbulent region of the high-Reynolds-number boundary layer using an atmospheric flow. J Fluid Mech 548:375-402

Lumley JL, Panofsky HA (1964) The structure of atmospheric turbulence. Wiley, Hoboken, 244 pp

Maronga B (2014) Monin-Obukhov similarity functions for the structure parameters of temperature and humidity in the unstable surface layer: Results from high-resolution large-eddy simulations. J Atmos Sci 71:716-733 
Maronga B, Gryschka M, Heinze R, Hoffmann F, Kanani-Shring F, Keck M, Ketelsen K, Letzel MO, Sühring M, Raasch S (2015) The parallelized large-eddy simulation model (PALM) version 4.0 for atmospheric and oceanic flows: model formulation, recent developments, and future perspectives. Geosci Model Dev $8: 2515-2551$

Marusic I, Monty JP, Hultmark M, Smits AJ (2013) On the logarithmic region in wall turbulence. J Fluid Mech 716:R3-1-R3-11

Monin AS, Yaglom AM (1971) Statistical fluid mechanics: mechanics of turbulence, vol 1. The MIT Press, Cambridge, $769 \mathrm{pp}$

Physick WL, Garratt JR (1995) Incorporation of a high-roughness lower boundary into a mesoscale model for studies of dry deposition over complex terrain. Boundary-Layer Meteorol 74:55-71

Raupach MR, Legg BJ (1984) The uses and limitations of flux-gradient relationships in micrometeorology. Agric Water Manag 8:119-131

Raupach MR, Antonia RA, Rajagopalan S (1991) Rough-wall turbulent boundary layers. Appl Mech Rev 44:1-25

Stoll R, Porté-Agel F (2008) Large-eddy simulation of the stable atmospheric boundary layer using dynamic models with different averaging schemes. Boundary-Layer Meteorol 126:1-28

Sullivan PP, Weil JC, Patton EG, Jonker HJJ, Mironov DV (2016) Turbulent winds and temperature fronts in large-eddy simulations of the stable atmospheric boundary layer. J Atmos Sci 73:1815-1840

Tennekes H (1973) The logarithmic wind profile. J Atmos Sci 30:234-238

Townsend AA (1976) The structure of turbulent shear flow, 2nd edn. Cambridge University Press, Cambridge, $428 \mathrm{pp}$

Udina M, Sun J, Kosović B, Soler MR (2016) Exploring vertical turbulence structure in neutrally and stably stratified flows using the Weather Research and Forecasting-Large-Eddy Simulation (WRF-LES) model. Boundary-Layer Meteorol. doi:10.1007/s10546-016-0171-8

Wyngaard JC (2010) Turbulence in the atmosphere. Cambridge University Press, Cambridge, MA, 406 pp 